\title{
SZEMLE
}

Miskolczi Csulyak István peregrinációs albuma, Kísérőtanulmányok Jakó Zsigmond, Oláh Róbert, Sárospatak, Debrecen, Hernád Kiadó, TTRE Nagykönyvtára, 2018. 1083 p. (Facsimile kiadás.)

Manapság, amikor az internet segítségével unikális könyv, illetve kéziratok is könnyen elérhetővé válnak, nagy szakmai és anyagi elszánást igényel egy terjedelmes papíralapú facsimile kiadás közreadása. A könyvgyüjtők, színvonalas ajándékozásra törekvők bizonyára örömmel forgatják majd Miskolczi Csulyak István peregrinációs albumát, de a művelődés-, irodalom-, egyetemtörténet tudósai is elgyönyörködve és újnál újabb adalékokat felfedezve veszik kézbe a terjedelmes kötetet.

A peregrinációs albumok müfaja az utóbbi évtizedekben vált az adatbázisalapú feldolgozás egyik kedvelt anyagává, és a korábban hozzáférhetetlen vagy hatalmas időt, energiát, különböző könyvtárak felkeresését, kéziratos anyagok lemásolását igénylő rengeteg információ kutatása vált az adatbázisok segítségével könnyebben elérhetővé. A peregrinációs albumok hazai adatbázisát OTKA támogatással Latzkovits Miklós és tudományos közössége hozta létre Inscriptiones Alborum Amicorum (a továbbiakban: IAA) címmel, és folytatja a hatalmas feltáró munkát, amely már a külföldi kutatók számára is alapvető segédletté válik. Mindezt mutatja, hogy az erlangeni egyetemen szerkesztett nemzetközi album amicorum adatbázis Repertorium Alborum Amicorum (a továbbiakban: RAA) már átvette a szegedi munkaközösség anyagát, tehát valóban egy nemzetközileg is elismert együttműködés részesei lehetnek a 16-19. századi müvelődéstörténet kutatói.

A peregrinációs albumok hasonmás kiadása nem túl gyakori, inkább egyes oldalak, érdekes bejegyzések kerülnek bele az külföldön járt diákok egyetemjárását feldolgozó írásokba. Az egyik nevezetes magyar album amicorum, amelynek teljes anyaga tanulmányozható, Pápai Páriz Ferenc európai peregrinációjának emlékkönyve 1711-1726, (htpp://ppf.mtak.hu/index.htm), a hozzáférés Rozsondai Marianne, Rozsondai Béla, Sajó Tamás és Láng Klára munkájának köszönhető. Az európai müvelődéstörténet adatokban és dekorációban egyaránt gazdag peregrinációs emlékkönyve az ifj. August braunschweig-lüneburgi herceg albuma 1594-1604 (facsimile kiadás: kiad. Wolfgang Harms, Marie von Katte, Stuttgart, Müller und Schindler, 1979), amelynek számos magyar vonatkozását már többen feldolgozták.

Miskolczi Csulyak István a Tiszáninneni Református közösség prédikátora hatalmas írásos hagyatékot hagyott maga után, szinte grafomán tevékenységét és eseményekben sem szükölködő magánéletét a korszak kutatói többféle nézőpontból tették hozzáférhetővé. Különösen kiemelendő verseinek kritikai kiadása (Pécseli Király Imre, Miskolczi Csulyak István és Nyéki Vörös Mátyás versei, sajtó alá rend. Jenei Ferenc, Klaniczay Tibor, Kovács József, Stoll Béla Bp., 1962 [Régi Magyar Költők Tára XVII. század, 23]). Az újabb szakirodalomból kiemelendő Szabó András tanulmánya, Miskolczi Csulyak István Heidelbergben (= Bibliotheca et Universitas, Tanulmányok a hatvanéves Heltai János tiszteletére, szerk. Kecskeméti Gábor, Tasi Réka, Miskolc, Miskolci Egyetem BTK, Magyar Nyelv- és Irodalomtudományi Intézet, 2011, 119-128.), valamint Oláh 
Róbert doktori disszertációja Miskolczi Csulyak István és Tofeus Mihály református lelkészek könyves müveltsége, (Debrecen, Debreceni Egyetem, 2016) [https://dea.lib.unideb.hu/dea/handle/ 2437/233384] [Letöltve: 2019. 05. 03.]).

Miskolczi Csulyak István (1575-1645) külföldi utazása abba a sorba illeszkedik, amely nem a saját, bár nagyon vágyott tanulmányi út emlékeit örökítette meg, hanem az anyagiakban, társadalmi helyzetben jóval magasabban elhelyezkedő Thököly Miklós (1587-1617) nevelöjeként tette meg az élményekben gazdag, ugyanakkor pozícióban lényegesen hátrányosabb, nagyobb önfegyelmet és kevesebb egyéni ambíciót követelő európai körutat. Thököly Miklós külföldi képzése hat évvel idősebb bátyja, Thököly István (1681-1651) példáját követi, de a nagyszabású európai körútból családi haláleset miatt csak a görlitzi és a heidelbergi tanulmányok valósulhattak meg - az emlékkönyvben szereplő városok az útvonalat jelzik -, többnyire rövidebb tartózkodással.

Miskolczi Csulyak István peregrinációs útjára nem e célból vásárolt üres emlékkönyvvel indult, hanem nagy tervekkel, gondosan felkészülve alakított ki egy müvelödéstörténetileg is fontos kiadványból saját használatú peregrinációs albumot. Kötetének alapját Nicolaus Reusnerus Icones sive imagines vivae litteris clarorum virorum Italiae, Graeciae, Germaniae, Galliae, Anglicae, Ungariae címü nevezetes munkája képezte, amelynek 1589. évi bázeli kiadását egybeköttette az 1590. évi strasbourgi kiadással. Jakó Zsigmond, aki először írt Miskolczi Csulyak albumáról, a kötet csonkasága miatt csupán az 1587-ben keletkezett előszóra utalva említi ezt a kiadást. Oláh Róbertnek sikerült feltárnia, hogy Reusner müvének 1587. évi kiadása nem ismert, utazónk Bernhard Jobin strasbourgi nyomtatványát használta. A két terjedelmes kötet még vastagabb lett a Miskolczi Csulyak által eltervezett sok bejegyzésre számító beköttetett üres lap miatt, viszont a facsimile kiadásban pótolni kellett a hányatott sorsú album hiányzó nyomtatott lapjait, és helyre kellett állítani a kötet sérült külső bőrkötését is. A restaurálás, az album szétbontása és teljes helyreállítása Wallinger Mónika restaurátor szakértelmét dicséri, ugyanakkor nem feledhető, hogy anyagi okokból mind az eredeti kötés hasonmása, mind a külső díszítés megvalósíthatatlan lett, és nyomdatörténetileg sem vizsgálható eredeti egészként a hasonmás, mert a különböző példányokból pótolt lapokkal egy teljesen új könyvészeti egység jött létre, amelynek müvelődéstörténeti jelentősége érdemel elismerést.

Miskolczi Csulyak István albumának bejegyzőit Jakó Zsigmond kronologikus rendben felsorolta, kiemelve a bejegyzés helyét, de a névaláírásokat nem oldotta fel vagy magyarázta meg, csupán a betűhív aláírásformát követte. Oláh Róbert a két tanulmányt követően névmutatót közölt, amely a szakirodalomban ismeretes neveket listázta, de nem alkalmazott az albumban használatos formákra vonatkozó utalókat. Ugyanakkor a kötet kezelését jelentősen megkönnyítette, hogy szögletes zárójelben folyamatos lapszámozással látta el a kötetet, így a nevek a facsimile kiadásban könnyen visszakereshetök. A visszakeresés fordított metódusa ugyan nem lett könnyebb, ha valaki pl. az 1089. lapon Michel P. Foctőinus nevét látja, Jakónál megtalálja Heidelberg városánál az 1609-es évnél, de a névmutatóban csupán a Foktövi Pastoris Mihály névnél sikerül a beazonosítás. A két - nagy időintervallumban, fáradságos munkával készült - tanulmány együttesen sem segít abban, hogy a bejegyzők személyéről információt nyerjünk és a többszáz kézírás kibetüzéséhez is más segítséghez kell fordulni. Szerencsére ez - köszönhetően Latzkovits Miklós és kutatócsoportja munkájának - ma már könnyen megoldható, hiszen az IAA adatbázisban minden bejegyzés hozzáférhető adata megtalálható. Tehát a dekoratív kötet és érdekes tanulmányok mellett a facsimile kiadás értelmezéséhez elengedhetetlen a szegedi adatbázis egyidejű használata is. A helyzet azonban még bonyolultabb, ha a peregrinációs album tulajdonosának és tanárainak, útitársait, egyetemi ismerősei kapcsolatrendszerét akarjuk feltárni Nagy segítséget nyújt ebben az erlangeni Repertorium Alborum Amicorum, amely teljes mértékben felhasználta a szegedi adatbázist, tehát az általa használt névanyagban visszakereshetők a Miskolczi Csulyaknál szereplő személyek is. 
Thököly Miklós és kísérője, Miskolczi Csulyak István peregrinációjának hálózatszerü kapcsolatrendszerét a manapság divatos kutatási módszereket alkalmazva Markó Anita már értelmezte (Hálózatok a 16-17. századi album amicorumokban az 1500 és 1700 közötti jellegü emlékkönyvbejegyzések hálózatelemzése az Inscriptiones Alborum Amicorum adatbázis alapján = Digitális Bölcsészet, 1(2018), 76-78), ennek ellenére sem haszontalan a facsimile kiadás és a két adatbázis névanyagának összevetése. Kevésbé lényeges, bár nem elhanyagolandó, hogy az adatbázisok, illetve a nyomtatott tanulmányok gyakran eltérő írásmódot használnak a névanyagban, sokkal érdekesebb azonban annak a szempontnak a nyomon követése, hogy milyen nevek és milyen mennyiségben fordulnak elő más peregrinusnaplókban, más országból származó diákok ismeretségi körében. Az egyik feltünő jelenségre Oláh Róbert is felhívta a figyelmet, a magyar peregrinusok legfontosabb egyetemi professzora nem szerepel a bejegyzők között, nem találjuk a bejegyzők között David Pareus nevét. Heidelbergben Miskolczi Csulyaknak három nyomtatott értekezése jelent meg, mindhárom esetben Pareus professzor volt a disszertáció praesese, és hazaérkezése után is levelezett híres professzorával. El kell fogadnunk Oláh Róbert magyarázatát, hogy mivel Thököly Sebestyén halála miatt a peregrinációt váratlan gyorsasággal meg kellett szakítani, éppen a jeles professzortól nem sikerült elbúcsúzni és bejegyzését az albumba megszerezni. A Jakó Zsigmond által felsorolt 170 bejegyzés közül a szegedi kutatócsoportnak 156 személy adatait, szövegeit sikerült beazonosítani, ami nagyon jelentős feltáró munkát bizonyít. Ugyanakkor nem eredménytelen az erlangeni adatbázis eredményét összevetni a szegedi IAA-val, mert érdekes összefüggésekre figyelhetünk fel. A Repertorium Alborum Amicorum 2019. január 15-i összegzése szerint az adatbázis 25000 albumot ismer, ebből 3700 album anyagát építette be az adatbázisba, 261000 bejegyzés rögzítésével. Ez az imponáló mennyiség természetesen tartalmazza az IAA adatait is, de találunk sok olyan hungarika vonatkozású személy-, helynevet, beírást, amelyek még nem jutottak el a szegedi kutatók autopszián alapuló feldolgozásáig. Miskolczi Csulyak albumbejegyzői közül nem találjuk az RAA által rögzített anyagban a következő neveket: Arvinus, Johannes, Csulai (Czulaj) György, Debreceni András, Foktövi Pastoris Mihály, Funkenstein, Wenzeslaus, Gravinus Ludovicus, Homonnai Drugeth Bálint, Huszti N. Zsigmond, Máriássy Ferenc, Ráczkevi (Ratskevinus) Stephanus, Váradi Pellionis Mihály, Vizsolyi Hunyor János, Zombori Tarcal Péter.

Megengedve, hogy a német kollégák esetleg más névlakban rögzítették a felsorolt peregrinusok nevét, a fent említett hatalmas adatmennyiség ismeretében mégis elgondolkodtató, hogy ennyi név nem szerepel az eddig feltárt albumok tömegében. Természetesen csak találgathatunk, de megkockáztatjuk azt a feltételezést, hogy a magyar diákok kapcsolatrendszere meglehetősen zárt volt, esetleg nyelvtudás hiányában nem nagyon érintkeztek idegen anyanyelvü tanulótársaikkal. A bejegyzők közül a leggyakoribb azonosság Miskolczi Csulyak István és Tolnai Beke Mihály ismeretségi körében van, ez utóbbi albumát Imre Mihály ismertette meg a tudományos közvéleménynyel (Tolnai Beke Mihály heidelbergi peregrinációs albuma 1592-1596-ból = Könyv és Könyvtár, Debrecen, XVI, 1991, 19-39.) Ugyan a két magyar peregrinus nem azonos időben tartózkodott Heidelbergben, mégis megtaláljuk mindkettejük emlékkönyvében Jakob Christmann, Ludovicus Gravinus, Jan Gruter, Quirinius Reuter, Henrich Smet, Simon Sten, bejegyzését. Jakob Christmann arabista és csillagász, Jan Gruter történész-polihisztor, Quirinius Reuter a teológia professzora, Henrich Smet humanista tudós, orvos, Simon Sten történész, irodalomtörténész, valamennyien heidelbergi professzorok, azért kerülhetett a bejegyzésük a tíz év eltéréssel az egyetemi városban tartózkodó magyar diákok emlékkönyvébe. Három azonos személy szerepel Miskolczi Csulyak István és Horváth Stansith Márk emlékkönyvében (MOL P 1845.7.), különösen érdekes, hogy Melchior Jöstel matematikus professzor ugyanazt a görög bejegyzést írta Miskolczi Csulyak emlékkönyvébe 1603. július 4-én Wittenbergben, mint Horváth-Stansith albumába 1603. február 11-én Drezdában. Ugyancsak szerepel Jacobus Cocus wittenbergi medicus és Friedrich Taubmann wittenbergi poétika professzor mindkét magyar diák albumában. Caspar Dornau/Dornavius görlitzi rektor, majd 
a szász rendek követe Briegben nemcsak Miskolczi Csulyak albumába írt 1602 júniusában Görlitzben, hanem Fröhlich Dávid emlékkönyvébe is majd' húsz évvel később Briegben, továbbá Szulyovszky Balázs albumába Besztercebányán 1620-ban. Dornau kétszer járt magyar nyelvterületen, ebben az évben mint a szász rendek orátora vett részt a besztercebányai országgyúlésen, a következő évben már Briegben volt, ahol Fröhlichhel találkozott. A bejegyzések külön érdekessége, hogy Dornau nyilván az általa gyakran használt hippokratészi idézettel kezdte mindhárom bejegyzését (Aphorismi, Hip.2.51.), majd hosszabb, de már eltérő latin idézeteket írt az magyar diákok albumába. Ugyancsak azonos szerzőt, Bobrowiczi Mátyást találjuk az albumban 1602-ben Miskolczi görliczi tartózkodásakor, és Fröhlich Dávid emlékkönyvében már itthon 1616-ban Késmárkon, de nem azonos idézettel. Szenci Molnár Albert már a peregrinációból visszatért Miskolczi Csulyaknak írt latin és magyar jókívánságokat 1629-ben Olaszliszkán, Fröhlich Dávid emlékkönyvében pedig 1630-ban, Kolozsvárott találjuk meg a bejegyzését. Wolfgang Amling anhalti szuperintendens bejegyzését megtaláljuk Miskolczi Csulyaknál és Martinus Zehl emlékkönyvében is. A beírás érdekessége, hogy a teológiaprofesszor Zerbstben találkozott mindkét diákkal, Zehllel 1592-ban, Miskolczi Csulyakkal pedig 1603-ban, ám mindkettőjük emlékkönyvébe ugyanazt a görög bibliai idézetet írta (Sirah.4.28.). Utaltunk rá, hogy kevés bejegyző diák található meg külföldi iskolatársaik emlékkönyvében, néhányukat mégis megemlítve, az RAA nyilvántartása szerint Bocatius öt, Jacobus kettő, Abraham von Kreckwitz öt, Paulus Melissus kettő, Martin Mylius három, Quirinius Reuter kettő kortárs emlékkönyvben szerepel. Külön ki kell emelni, hogy Johann Albrecht zu Solms-Braunfels heidelbergi föudvarmester és államminisztertől, nyilván magas pozíciójának köszönhetően, eddig tizenegy album amicorum bejegyzést ismerünk, Miskolczi Csulyak 1607-ben Heidelbergben, hirtelen hazautazása előtt tett nála búcsúlátogatást.

A facsimile kiadás tanulmányozása, a kísérőtanulmányok névanyagának az IAA és az RAA adatbázisának összevetése néhány eltérés felfedezését eredményezte, ami nem zárja ki, hogy többször is előfordulhat be nem azonosított személy más névalakkal. Utaljunk csak arra, hogy az IAA 14 személyt nem tudott beazonosítani. A futólagos összevetés után például az IAA-ban és az RAAban Johannes Fersius szerepel, a névmutatóban és az albumban helyesen Johannes Ferschius. Az album 805. oldalán Matthias Erbinaeus bejegyzése olvasható, és ezt a névalakot rögzítette a két internetes adatbázis is, a kötet névmutatójában Matthias Erben von Brandau neve található. Mivel a névmutató nem utal eltérő névalakokra, nehéz beazonosítani Simeon Valerius Rundus nevét, akit mind a szegedi, mind az erlangeni adatbázis Valerius de Luna néven szerepeltet. Jakó Zsigmond betühív olvasata szerint Simeon Valetrus(!) Lunaeus olvasható a kötetben. A kézirat alapos kibetüzése az adatbázisok névalakját erősíti meg.

A terjedelem szorította kényszer miatt rövidre fogott Oláh Róbert tanulmány szinte minden fontos adatot tartalmaz a peregrinációs album történetéről, és elhelyezi azt és tulajdonosát az egyetemjáró diákok között. A 17. századi peregrinációtörténethez értékes forrás közreadásával járult hozzá a Hernád Kiadó, és mindenekelőtt köszönet illeti az albumot őrző Jakó Klárát és a korrekt összefoglaló tanulmányt író és mikrofilológiai gondossággal összeállított névmutatót készítő Oláh Róbertet, akinek - remélhetőleg - hamarosan Miskolczi Csulyak Istvánnal foglalkozó doktori diszszertációját nyomtatásban is megismerhetjük.

NÉMETH S. KatALiN

\section{Három körösztyén leány, Az első magyar nyelvű dráma, közreadja Dömötör Adrienne, a latin szöveget átírta, fordította Szentgyörgyi Rudolf, Budapest, Balassi Kiadó, 2018. 127 p.}

Az igényes könyvecske borítóját egy fametszet díszíti: három szemérmesen mosolygó, meztelen keblét takargató leány áll egy lángoló máglyán, balról a török császár ítélkezik felettük, jobbról egy német katona kardjával segédkezik. A kép Albrecht Dürer és Hans von Kulmbach metszet- 